\title{
Family Support Relationship With Playing Activities Of 5-6 Years Old Children In The Pandemic Period
}

\author{
Andi Azifa Adillah Amhar ${ }^{1}$, Tenriwati ${ }^{2 *}$, Nadia Alfira ${ }^{3}$ \\ ${ }^{1}$ Nursing Student, Stikes Panrita Husada Bulukumba, Indonesia \\ ${ }^{2,3}$ Department of Nursing Stikes Panrita Husada Bulukumba, Indonesia
}

Corresponding author: Tenriwati

Email: tenriwatisalala@gmail.com

\begin{abstract}
Play and children are an inseparable unity. Every activity carried out by children will always indicate play activities. Playing is very important for early childhood because through play it develops aspects of child development. The importance of fulfilling play when children are at home requires full support from the family to improve children's development in all aspects considering that at this time children's schools are closed and children's activities must be fully carried out at home. This research design used a cross-sectional study design. The sampling method used was nonprobability sampling, namely the purposive sampling technique. The research sample was 36 respondents. The research was conducted in August. Research by measuring or observing at the same time (Point Time Approach). The results of the study, namely the results of fisher's alternative chi-square test obtained $p$-value $=0.008$ in the sense that the $\mathrm{p}$-value is smaller than the value of $\alpha=0.05$. There is a significant relationship between family support and children's play activities. It is hoped that this research can become information material for parents in accompanying their children during the pandemic and always accompanying children while playing both during the pandemic period and after the pandemic has passed.
\end{abstract}

Keywords : Family Support, Play 


\section{PENDAHULUAN}

Sehat merupakan suatu keadaan tanpa gangguan dalam diri seseorang seutuhnya yang meliputi, kesehatan fisik, mental, maupun sosial yang menjadi satu kesatuan yang tidak terpisahkan. Menurut WHO sehat adalah keadaan yang meliputi sehat fisik, mental, dan bukan hanya keadaan bebas dari penyakit yang terlihat seperti cacat dan kelemahan. Bermain dan anak adalah suatu kesatuan yang tidak dapat terpisahkan. Setiap aktivitas yang dilakukan anak akan selalu menunjukkan kegiatan bermain. Bermain merupakan kegiatan yang tidak akan pernah terlepas dari anak. Bermain merupakan suatu cara yang dilakukan untuk melatih konsentrasi anak untuk mencapai kemampuan yang maksimal ketika terfokus pada kegiatan bermain dan saat mengeksplorasi mainannya. Bermain memberikan suatu konstribusi secara alamiah pada anak untuk dapat belajar dan berkembang. Tidak ada program yang dapat menjadi pengganti pengamatan, aktivitas, serta pengetahuan anak secara langsung pada saat bermain (Christianti, 2007).

Berdasarkan data WHO jumlah penduduk dunia menjapai 7,53 miliar jiwa dengan jumlah terbanyak anak usia 0-4 tahun 662 juta dan 5-9 tahun 618 juta. Sementara jumlah anak di Indonesia berdasarkan data profil anak Indonesia tahun 2018 mencapai 79,5 juta jiwa dengan kelompok usia 0-17 tahun, sementara jumlah anak usia 0-17 tahun untuk sulawesi selatan sekitar 2,59 juta jiwa. Untuk membangun peradaban yang unggul maka perlu mengembangkan generasi mudanya yang dimulai saat masih berusia dini. Metode yang dapat dilakukan untuk anak adalah dengan bermain, sebagaimana pandangan bahwa anak bermain sambil belajar. Kegiatan yang dapat dilakukan anak adalah dengan mengikuti progam pendidikan anak usia dini (PAUD) yang dimana kegiatan-kegiatan yang dilakukan salah satunya adalah permainanpermainan yang dapat meningkatkan perkembangan anak disegala aspek (Yus, 2011).

Keterlibatan anak di Indonesia dalam mengikuti pendidikan usia dini dapat dilihat dari angka partisipasi kasar (APK) PAUD untuk anak usia 3-6 tahun di Indonesia sekitar 33,45 \%. Angka partisipasi PAUD antar provinsi Yogyakarta menempati urutan pertama sebesar $65,80 \%$, dan terendah provinsi Papua sebesar 10,65\%, provinsi sulawesi selatan sendiri APK PAUD sebesar $26,81 \%$. Sedangkan jenis PAUD yang paling banyak diikuti anak 0-6 tahun adalah TK dengan persentase sebesar 60,66\%. Data yang diperoleh dari Dinas Pendidikan Kabupaten Bulukumba tahun 2020 dimana jumlah TK(Taman Kanak-kanak) yang merupakan lembaga pendidikan formal lebih banyak dibandingkan dengan KB (Kelompok Bermain) yang 
merupakan lembaga pendidikan nonformal. Untuk kecamatan Ujung Bulu yang dijadikan sebagai wilayah penelitian terdapat 49 PAUD meliputi 43 TK dan 6 KB. Di dunia saat ini sedang menghadapi suatu pandemi penyakit termasuk di Indonesia. Pemerintah kemudian membuat aturan untuk tetap tinggal dirumah, bekerja dirumah, serta belajar dirumah. Dampak dari aturan ini adalah diliburkannya sekolah-sekolah termasuk sekolah PAUD. Secara tidak langsung siswa-siswi sekolah PAUD akan kehilangan sementara media bermainnya karena sebagian waktu bermain mereka dilakukan saat sekolah.

Perkembangan anak dipengaruhi oleh lingkungan sekitarnya tempat ia berada. Apabila dukungan keluarga baik makan pertumbuhan serta perkembangan anak akan relatif stabil, namun jika dukungan keluarga kurang baik maka akan menghambat anak dan mengganggu psikologis anak (Alimul, 2005). Ibu lebih besar memberikan dukungan daripada ayah, karena ibulah yang merawat anak sejak mengandung, melahirkan hingga masa pertumbuhan anak (Miranda, 2013). Ibu memiliki lebih banyak informasi dalam hal mengasuh anaknya dibandingkan ayah yang lebih fokus pada finansial dalam membesarkan anak. Orang tua di rumah sebagai pendidik anak mempunyai peran yang sangat penting pada proses perkembangan anak.

Berdasarkan penelitian yang dilakukan oleh Ade Holis dengan judul belajar melalui bermain untuk pengembangan kreativitas dan kognitif anak usia dini mengemukakan bahwa terdapat perbedaan yang signifikan terhadap peningkatan kreativitas dan kognitif anak usia dini antara kelompok kontrol dan kelompok eksperimen yang diberikan permainan balok pada TK Al Kautsar di Kabupaten Garut. Hasil penelitian yang dilakukan oleh Minta Ito Harahap dengan judul hubungan support system keluarga dengan tingkat kecemasan pada anak pra sekolah akibat hospitaliasi di RSU imelda pekerja menunjukkan terdapat hubungan antara support system keluarga dengan kecemasan anak dengan uji statistik pada tingkat kepercayaan $95 \%$ diperoleh $\mathrm{p}=0,023<$ dari $\alpha=0,05$. Dari hasil penelitian tersebut dapat disimpulkan bahwa dukungan keluarga terhadap anak sangat dibutuhkan baik saat anak sakit maupun saat anak sehat dengan memberikan dukungan yang sesuai dengan tahap perkembangannya.

Tujuan penelitian ini adalah untuk mengetahui hubungan dukungan keluarga dengan kegiatan bermain anak usia 5-6 tahun pada masa pandemi di TK Idatha 1 Bulukumba. 


\section{BAHAN DAN METODE}

\section{Desain Penelitian}

Desain penelitian yang digunakan pada peneliti adalah Cross Sectional study yaitu rancangan penelitian dengan melakukan pengukuran atau pengamatan pada saat bersamaan (sekali waktu) untuk mengetahui hubungan dukungan keluarga dengan pemenuhan bermain anak di TK Idatha 1 Bulukumba. Diobservasi pada suatu saat (Point Time Approach) artinya setiap subjek atau sampel penelitian diobservasi sekali saja.

\section{Populasi dan Teknik Sampel}

Populasi dalam penelitian ini adalah seluruh siswa dan siswi TK Idatha 1 Bulukumba yang berusia 5-6 tahun yang berjumlah 39 orang pada tahun 2020. Jumlah sampel dalam penelitian ini sebanyak 36 responden yang di dapatkan dari siswa dan siswi TK Idatha 1 Bulukumba yang berusia 5-6 tahun yang berjumlah 36 orang pada tahun 2020 dengan menggunakan rumus slovin. Tehnik pengambilan sampel dalam penelitian ini adalah tekhnik Nonprobability sampling yaitu dengan teknik Purposive sampling.

\section{Instrumen Pengumpulan Data}

Instrument dalam penelitian ini adalah kuesioner (angket) dan lembar observasi. Kuesioner digunakan untuk mengumpulkan data tentang umur, jenis kelamin, tingkat pendidikan, dan dukungan keluarga responden. Lembar observasi digunakan untuk mengumpulkan data kegiatan bermain anak.

\section{Analisa Data}

Data dianalisis berdasarkan skala ukur dan tujuan penelitian dengan menggunakan perangkat lunak program komputerisasi. Data dianalisis secara Univariat, Analisis dilakukan untuk melihat proporsi sedangkan Analisis Bivariat, Uji bivariat dilakukan untuk mencari hubungan antara variabel independen dan variabel dependen dengan uji yang digunakan adalah chi Square alternatif fisher.

\section{HASIL}

Berdasarkan (Tabel 1) Jumlah responden pada penelitian ini berjumlah 36 responden. Karakteristik subyek penelitian meliputi jenis kelamin, umur, dan pendidikan. Jenis kelamin responden yaitu perempuan (77,8\%), tingkat pendidikan yaitu SMA $(52,8 \%)$, Umur responden yaitu (30-40 tahun) $(58,3 \%)$. 
Tabel 1. Distribusi Frekuensi Berdasarkan Karakteristik Responden

\begin{tabular}{cccc}
\hline \multicolumn{2}{c}{ Karakteristik responden } & Frekuensi (f) & Persentase (\%) \\
\hline Usia & $21-30$ tahun & 15 & 41.7 \\
& $31-40$ tahun & 21 & 58.3 \\
\hline \multirow{2}{*}{ Jenis Kelamin } & Laki-laki & 8 & 22.2 \\
& Perempuan & 28 & 77.8 \\
\hline \multirow{2}{*}{ Pendidikan } & SMP & 4 & 11.1 \\
& SMA & 19 & 52.8 \\
& Diploma & 2 & 5.6 \\
& Sarjana & 11 & 30.6 \\
\hline
\end{tabular}

Berdasarkan Tabel 2 menunjukkan distribusi jumlah responden berdasarkan dukungan keluarga dan kegiatan bermain anak. Untuk dukungan keluarga menunjukkan bahwa yang memiliki dukungan keluarga cukup sebanyak 91,7\%. Sedangkan jumlah responden berdasarkan kegiatan bermain anak dengan kategori anak bermain sebanyak 77,8\%.

Tabel 2. Distribusi frekuensi dukungan keluarga dan Kegiatan Bermain anak

\begin{tabular}{lcc}
\hline \multicolumn{1}{c}{ Dukungan Keluarga } & Frekuensi (f) & Persentase (\%) \\
\hline Cukup & 33 & 91.7 \\
Kurang & 3 & 8.3 \\
\hline Kegiatan Bermain & & \\
\hline Bermain & 28 & 77.8 \\
Tidak bermain & 8 & 22.2 \\
\hline \multicolumn{1}{r}{ Total } & $\mathbf{3 6}$ & $\mathbf{1 0 0}$ \\
\hline
\end{tabular}

Berdasarkan (Tabel 3) menunjukkan hubungan Berdasarkan hasil uji Chi Square alternatif fisher didapatkan nilai $p=0.008(<\alpha=0.05)$ yang artinya ada hubungan yang signifikan antara dukungan keluarga dengan kegiatan bermain anak. 
Tabel 3. Hubungan Dukungan Keluarga Dengan Kegiatan Bermain Anak

\begin{tabular}{lccccccc}
\hline & \multicolumn{6}{c}{ Kegiatan Bermain } & \\
\cline { 2 - 7 } $\begin{array}{l}\text { Dukungan } \\
\text { Keluarga }\end{array}$ & Bermain & \multicolumn{2}{c}{$\begin{array}{c}\text { Tidak } \\
\text { bermain }\end{array}$} & Total & P Value \\
\cline { 2 - 7 } & $\mathbf{f}$ & $\mathbf{\%}$ & $\mathbf{f}$ & $\mathbf{\%}$ & $\mathbf{n}$ & $\mathbf{\%}$ & \\
\hline Cukup & 28 & 100 & 5 & 62.5 & 33 & 91.7 & \\
\hline Kurang & 0 & 0 & 3 & 37.5 & 3 & 8.3 & \\
\hline Total & $\mathbf{2 8}$ & $\mathbf{1 0 0}$ & $\mathbf{8}$ & $\mathbf{1 0 0}$ & $\mathbf{3 6}$ & $\mathbf{1 0 0}$ & \\
\hline
\end{tabular}

\section{PEMBAHASAN}

Pada penelitian ini terlihat bahwa terdapat hubungan yang bermakna antara dukungan keluarga dengan kegiatan bermain anak.. Pada analisis dengan menggunakan uji chi square alternativ fisher didapatkan nilai $p=0.008$ lebih kecil dari nilai $\alpha=0.05$.

Faktor-faktor yang mempengaruhi kegiatan bermain anak menurut (Hurlock, 2011) diantanya kesehatan anak, perkembangan motorik, inteleensi, jenis kelamin, lingkungan dan taraf sosial ekonomi, alat permainan. Secara garis besar dukungan keluarga termasuk dalam faktor yang mempengaruhi kegiatan bermain anak. Namun dukungan keluarga merupakan sesuatu faktor yang melebur didalam faktor lingkungan dan taraf sosial ekonomi. Dalam penelitian ini terdapat hubungan yang signifikan antara dukungan keluarga dengan kegiatan bermain anak artinya dukungan orang tua sangat berperan penting didalam kegiatan keseharian anak dalam memilih permainan edukaif serta permainan yang disukai oleh anak. Menurut (Ayuni, 2020) dukungan keluarga sangat berperan penting, karena keluarga dapat memberikan sebuah dorongan baik fisik maupun mental dengan fungsi dukungan informasional, dukungan penilaian atau penghargaan, dukungan instrumental, dan dukungan emosional.

Peneliti berasumsi dukungan keluarga dalam hal ini peran dari orang tua, ayah maupun ibu sangat diperlukan dalam hal kegiatan bermain anak. Perlu adanya peran orang tua agar anak dapat memilih permainan yang tepat untuk anak sehingga anak tidak akan merasa bosan jika berada dirumah selama penerapan PSBB yang mengharuskan anak untuk tetap tinggal dirumah. Dukungan keluarga sangat berpengaruh terhadap bagaimana anak dalam bermain dan https://doi.org/10.37362/jlb.v4i3.523 
permainan apa yang akan dilakukan anak. Dukungan keluarga yang baik dapat membuat anak dapat bermain dengan nyaman karena tidak tertekan dengan orang tua yang melarang atau membatasi anak bermain. Meskipun dukungan keluarga baik namun masih banyak faktor yang mempengaruhi anak dalam bermain, beberapa faktor yang mempengaruhi anak dalam kegiatan bermainnya adalah kesehatan anak, tingkat intelegensi anak, jenis kelamin, lingkungan, status sosial, alat permainan yang dimiliki, serta perkembangan anak. Dalam penelitian ini juga didapatkan data bahwa dari 36 responden anak terdapat 18 anak yang memainkan lebih banyak permainan tradisional dan 18 anak yang lebih banyak memainkan permainan modern. Dukungan keluarga juga dalam hal ini juga memiliki pengaruh terhadap anak dalam memilih jenis permainan meskipun lingkungan anak yang memiliki andil yang besar dalam menentukan jenis permainan yang akan dimainkan oleh anak.

\section{KESIMPULAN DAN SARAN}

Berdasarkan hasil peneltian yang dilakukan dapat disimpulkan bahwa ada hubungan yang signifikan antara dukungan keluarga dengan kegiatan bermain anak. Diharapkan dengan adanya penelitian ini dapat menjadi bahan informasi untuk orang tua dalam mendampingi anaknya selama masa pandemi dan selalu mendampingi anak saat bermain baik saat masa pandemi maupun setelah pandemi berlalu karena dengan keterlibatan orang tua dalam kegiatan bermain anak menjadikan bentuk permainan anak akan lebih bervariasi dan menjalin kedekatan orang tua dan anak serta anggota keluarga lain dengan anak

\section{DAFTAR PUSTAKA}

Alimul Aziz, H. (2008). Pengantar Konsep Dasar Keperawatan. Edisi2. Jakarta: Salemba Medika

Andika S, D., Nurul M, R., Yulianingsih, I., Astari T, T., \& Bafen, M. (2020). Kesiapan Ibu Bermain Bersama Anak Selama Pandemi Covid-19. Jurnal Obsesi: Jurnal Pendidikan Anak Usia Dini, 476-489.

Anita Yus. (2011). Model Pendidikan Anak Usia Dini. Jakarta: Kencana

Ardiana, D. (2011). Tumbuh Kembang \& Terapi bermain Pada Anak. Jakarta: Salemba Medika 
Christianti, M. (2007). Aspek-aspek perkembangan Pembiasaan Anak Usia Dini. Jakarta: Rineka Cipta.

Dharma, K. (2017). Metodelogi Penelitian Keperawatan. Jakarta: CV. Trans Info Media.

Harnilawati. (2013). konsep dan Proses Kepawatan Keluarga. Makassar: Pustaka As Salam.

Hasnida. (2015). Analisis Kebutuhan Anak Usia Dini. Jakarta

Hidayat, A. A. (2008). Pengantar Konsep Keperawatan. Jakarta: Salemba Medika.

Mayke, T. (2001). Bermain, Mainan, dan Permainan. Jakarta: PT Grasindo.

Masitoh, Et Al. (2006). Strategi Pembelajaran TK. Jakarta: Universitas Terbuka

Mulyasa. (2014). Manajemen PAUD. Bandung: Remaja Rosdakarya

Mutiah, D. (2010). Psikologi Bermain Anak Usia Dini. Jakarta: Kencana.

Notoatmojo, S. (2012). Metodologi Penelitian Kesehatan. Jakarta: Rineka Cipta

Sofia Hartati. (2005). Perkembangan Belajar Pada Anak Usia Dini. Jakarta: Depdiknas

Sudarsana. (2014). Pendidikan Anak Usia Dini Berkarakter. Yogyakarta: Genius Publisher.

Sugiyono. (2017). Metode Penelitian Kuantitatif, Kualitatif, Dan R\&D. 26th Edn. Bandung: Alfabeta.

Susanto, A. (2011). Perkembangan Anak Usia Dini. Jakarta: KENCANA PRENADA MEDIA GROUP.

Syarbini, Amirulloh. (2014). Model Pendidikan Karakter dalam Keluarga. Jakarta:PT.Gramedia

Yus, A. (2011). Model Pendidikan Anak Usia Dini. Jakarta: Prenadamedia Group. 